\title{
ISLAM AND ITS REFLECTION IN RUSSIAN SCIENTIFIC LITERATURE
}

\author{
L'ubomír Čech \\ University of Economics in Bratislava, Slovak Republic
}

When it comes to Islam in general, there is a growing interest in its specific characteristics and practices in all spheres of society. The same applies to academic discussions and communities in the Russian Federation. In the first part of this paper, we analyse the Islamic revival in Russia. The second and the third parts present our analysis of scientific literature carried out on the basis of the Web of Science databases as well as major research areas and selected aspects of contemporary discourse.

Keywords: Islam; Russian Federation; scientific discussion

\section{Introduction}

Islam is currently the central topic in many discussions. It is facing serious challenges that lead to extremely divided opinions on the processes and phenomena existing in the Muslim world. We can state there are several reasons for this, including growing Islamic radicalism, extremism and terrorism, the rise of the Muslim diaspora caused by labor migration and the increased influx of migrants as well as demographic dynamics overall.

These factors constitute the basis for social tensions and various conflict-prone manipulations. The aforementioned challenges are being faced by the Russian Federation as well, in which they are also associated with its involvement in conflicts and wars in the Middle East.

As a result, the Islamic factor is often viewed from the perspective of potential danger and/or unpredictability. However, deep roots of Islam in Russia prevent these views from being based exclusively on hateful words. The Muslims in the Russian Federation have always been an integral part of the country's historical legacy, thus, they are never regarded as foreigners and their population is far too large to be overlooked as such.

Religious revival in Russia currently poses several major challenges, including particularly establishment of religious identity principles, ensuring national values integrity,

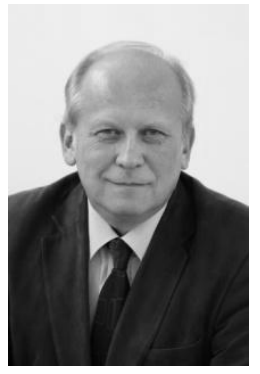

\section{L'ubomír Čech}

Doctor of History, Associate Professor

Head of the Department of International Political Relations, Faculty of International Relations, University of Economics in Bratislava, Slovak Republic

ORCID ID: 0000-0002-8406-9480

Research interests: international relations; Islam and its influence on political and economic relations; security relation between the Asian countries.

E-mail: lubomir.cech@euba.sk 
seeking new logic and philosophy of the national politics and tackling the threats related to religious radicalism. Political connotations of the religious factor in the Russian Federation imply the identification of new meanings and phenomena that intersect with religion, politics and society at the same time. The aforementioned challenges require the analysis of the role Islam and Muslims in the Russian Federation within the context of scientific discussions and debates.

The purpose of this paper is to outline the main features of the contemporary scientific discussion on Islam and its revival in the Russian Federation by analysing scientific publications on the related topics.

\section{Islam's growing importance in Russia}

The last two decades have witnessed the rapid growth of Islam in the Russian Federation and other former Soviet republics, including the construction of mosques, the expansion of business activities and Islamic education as well as Islam awareness campaigns. Islam is spreading beyond historically Muslim regions and it does not always follow traditional models only. In addition, Muslim communities are undergoing considerable changes due to their demography and migration. While the ethnic Russian population is shrinking, the Muslim population in Russia is growing, and quite rapidly. This demographic situation might pave the way for Islam to become the predominant religion in the country in the near future already.

Given the current developments in its economy, Russia needs to look for new sources of economic growth. Due to its economic and political conflicts with Western countries, it is searching for new markets too. Prospects for cooperation might help overcome the isolation caused by the EU and U.S. sanctions and bring necessary alleviation. The vectors of Russian foreign policy can be clearly seen in the Muslim world, especially in the Middle East, where Russia is taking advantage of the region's proximity and promoting its active diplomacy. Recent developments indicate that Moscow has to and wants to acknowledge the Islam's growing role in the political and social life of the Russian Federation.

Nevertheless, there are some tensions between Muslims and non-Muslims, stemming particularly from the conflicts in the North Caucasus, rising nationalism in Russian Muslim republics and the growing migration from the Central Asian countries.

The tensions also result from historical residues, tense relations with Afghanistan, Pakistan, Iran and Turkey, and last but not least, international and domestic terrorism. Antiimmigrant, anti-Caucasus and implicitly anti-Muslim sentiments have increased the feelings of alienation among many Russian Muslims.

In addition, promotion of moderate Islam is threatened by the attraction of radical Islam, which appeals mainly to its young adherents. It is necessary to clearly and pragmatically formulate social, cultural and religious needs of Islam in the country. This, however, requires a solid understanding of the roots of their present mutual relations.

Islam in the post-Soviet Russia is a complex issue, which can be explored from religious, political, cultural, ethnic, social and security perspectives, at different levels (local, regional, national and international) and in terms of different historical periods. It has been studied, for example, by A. Malashenko (1994; 2007; 2014), G. M. Yemelianova (2002; 2010; 2019), R. Silantiev (2005), A.A. Ignatenko (2004, 2005) and V.O. Bobrovnikov (2007). 


\section{ISLAM AND ITS REFLECTION IN RUSSIAN}

An unbiased study of the post-Soviet Islam requires a careful examination of its development during the Soviet era, which has already been carried out by A. Bennigsen (1986; 2011) and S. A. Zenkovsky (2001).

Since 1991 and on Islamic studies in Russia have been conducted independently of oriental studies. The issues concerning Islam in contemporary Russia have been explored, inter alia, by Arabists, such as R.G. Landa (1995), A.A. Kudryavtsev (2013) and C.M. Prozorov (1999, 2004), who specialise in the challenges of the Middle East and North Africa as well as global Islam and its politicization in the late 20th century.

The unique essence of the relationship between ethnic minorities in Russia and Islam is based on the fact that this religion has survived for centuries of coexistence as well as conflicts and repression.

The book by Ramet S. P. (2005), which brings together 15 of the West's leading scholars on this subject, provides a thorough and comprehensive analysis of the history of religion in the Soviet Union in general, tracing the anti-religious persecution during Stalinism and religious liberalization during the Gorbachev era. In his book titled "Religion, State and Politics in the Soviet Union and Successor States" J. Anderson (1994) provides the first systematic overview of the church-state relations in the Soviet Union and analyses the role of religion in the post-Soviet future (as of 1994).

The bureaucratic view on religion in the Soviet Union is presented in the extensive collection of annotated texts from the newly opened archives - "Religion in the Soviet Union: An Archival Reader" by F. Corley (1996). This collection includes documents from the KGB, the Central Committee, the Council for Religious Affairs and other public authorities.

Other valuable sources of information can be found in the publications dealing with the liberalisation process during the period of Gorbachev's perestroika, which encouraged national self-determination and opposition to the Soviet rule among the Central and Eastern European countries and some of the Soviet nations. These were, for example, the publications by M. R. Beissinger (2002), R. Keerana \& T. Kenny (2010), W. Slatera \& A. Wilson (2004).

Political connotations of the religious factor in the Russian Federation imply identification of new meanings and phenomena that intersect with religion, politics and the society (Mchedlova \& Kofanova, 2020: 8-9). This will require a cause-and-effect analysis of Islamic awakening.

\section{Islamic revival in scientific literature}

The history and the presence of Islam as well as the size of Muslim population in Russia attract a lot of attention in the scientific community nowadays. We used the Web of Science (WoS) platform as our primary source of data for the analysis of scientific literature focused on these issues. Since the number of scientific papers dealing with Islam in Russia is growing all the time, we used the WoS databases to determine the number of these publications. We have searched for attributes such as quantity, the country of origin, specific scientific fields and language, using the keywords "Islam" and "Russia" (Fig. 1).

We used the Web of Science (2021) databases and the aforementioned search terms to determine the number of publications between 1998 and 2020. We have found that this number is growing and the year 2019 saw 55 publications, which is the highest annual output 
of all (446 in total). Since Islam has become increasingly debated over the past years, we anticipate higher annual outputs in the near future.

Figure 1 - Publication outputs in WoS based on keywords "Islam" and "Russia" between 1998 and 2020

(Source: author's own calculations based on the Web of Science data (2021))

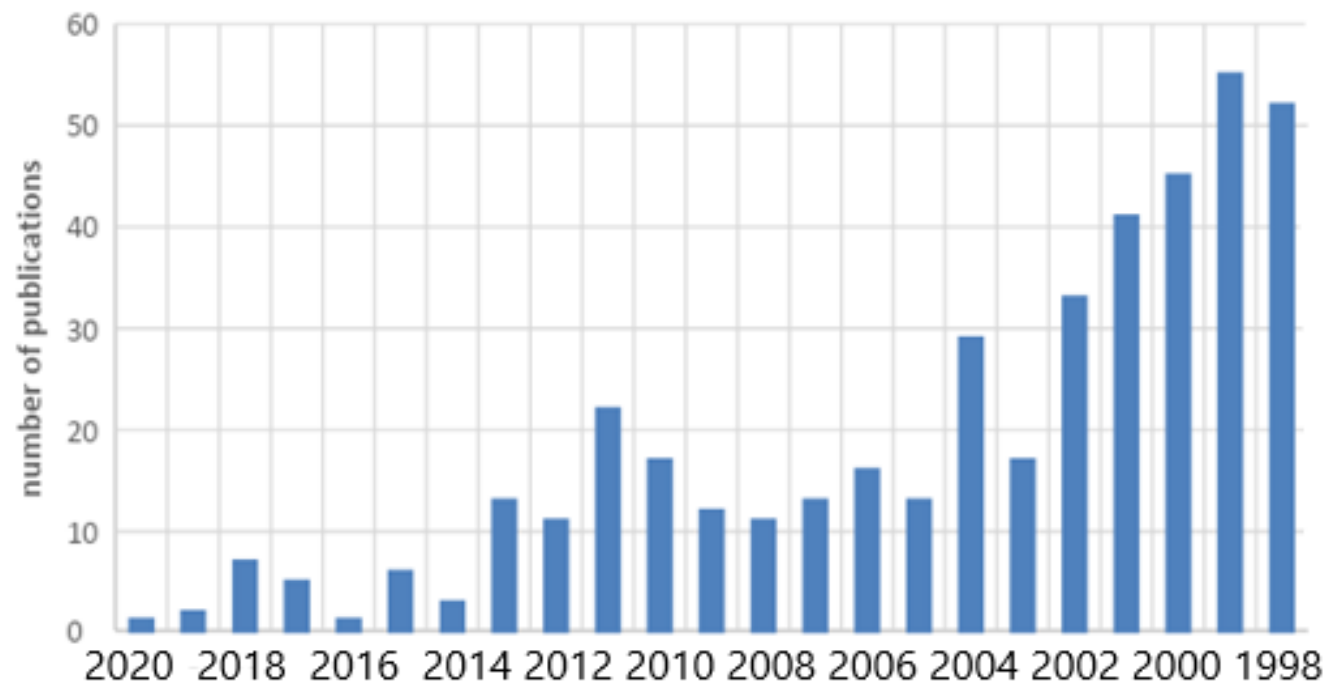

The year 2007, which saw a high number of publications, can be regarded as a landmark one. This publishing boom was probably caused by the impulse for scientific research stemming from the 2007 Government Decree as well as the Plan for training of specialists in Islamic culture and history focused on jobs in religious organisations and communities (clergymen and clergywomen, teachers in Islamic educational institutions, clerical administration staff and employees at publishing houses).

The year 2007 also saw the establishment of the Foundation for Islamic Culture, Science and Education, which awarded grants for educational, scientific and publication activities (Sapronova et al., 2020).

In this year, the number of publications had doubled in comparison with the previous period and since then, it has been growing rapidly, including mainly scientific papers (325), book reviews (81) and conference papers (25).

The majority of outputs were published in the following countries: the Russian Federation itself (179), the USA (88), the United Kingdom (28), the Netherlands (15), Turkey (12), Canada (10) and Kazakhstan (9). The number of publications in other countries was considerably lower. As far as the language is concerned, the majority of outputs were written in English (67\%), followed by Russian (27\%), Turkish (2.4\%), German (1.5\%) and French $(0.8 \%)$.

The table below shows the number of publications written between 1998 and 2020 according to specific disciplines (WoS categories), including History (with the highest number of outputs), Religion, Political Sciences, Regional Studies, Interdisciplinary Humanities, International Relations, Ethnic Studies, Sociology, Economics and so on. 
ISLAM AND ITS REFLECTION IN RUSSIAN

Table 1 - Number of research publications in WoS between 1998 and 2020, by specific disciplines

(Source: author's own calculations based on the Web of Science data (2021))

\begin{tabular}{|l|c|}
\hline History & 119 \\
\hline Religion & 74 \\
\hline Political Sciences & 72 \\
\hline Regional Studies & 54 \\
\hline Interdisciplinary Humanities & 43 \\
\hline International Relations & 33 \\
\hline Ethnic Studies & 21 \\
\hline Sociology & 19 \\
\hline Economics & 17 \\
\hline Interdisciplinary Social Sciences & 17 \\
\hline Educational Research & 11 \\
\hline Interdisciplinary Psychology & 9 \\
\hline Anthropology & 9 \\
\hline Law & 7 \\
\hline Geography & 7 \\
\hline
\end{tabular}

\section{Key areas of Islamic studies}

Today's world is undergoing profound changes due to the growing Muslim population in many Western European countries, globalisation, migration and the rise of radical Islamist groups. The emergence of ISIS, which openly sought to establish a global caliphate, has revived the debate on Islamic terrorism and aroused interest in Islam in general. These issues are of considerable significance in the Russian Federation due to its multi-faith population and specific sensitivity of the Islamic factor in numerous Russian regions. That is why their various aspects have been studied by political scientists, sociologists, anthropologists and other academic scientists.

A lot of scientific publications are focused directly on the relations between Russia and the Islamic world. Their authors study particularly demographic trends shaping the development of Muslim population in contemporary Russia, characteristics of Islamic culture, relationships between the Muslims and the followers of other religions, specific historical background regarding integration of the Muslims into Russian society as well as the coexistence of different ethnic groups within one country.

Research focused on regional aspects of Islam in today's Russia can be regarded as a separate scientific discipline. Indeed, it is impossible to understand general aspects of life of the Muslim communities in Russia and identify political, socioeconomic and religious root causes of the deteriorating situation in some regions of Russia without analysing specific ethnic and regional characteristics. This discipline is of utmost importance given the fact that migration processes are changing the ethno-religious landscape in different regions of the Russian Federation (Shmelev \& Potapova, 2015). 
The next area of research covers the relations between Islam and the state and also between the Islam and the political landscape in the Russian Federation. One of the most significant issues within this area is the state policy towards Islam. The research focuses on state-church relations and relationships between religion and society. Scientists working in this area analyse the relations between Islam and Orthodox Christianity as well as other religions traditionally present in Russia. Studying the relations between Sharia and the state laws is also vitally important. Another separate research area deals with the relations between Muslim indentity and citizenship as identity (Mirzakhanov, 2016).

M. Sapronova et al. (2018) have determined five major thematic areas in such publications written by Russian scientists:

- Theology, Islamic Philosophy and General Issues (Malashenko (1994, 2007, 2014; Bobrovnikov, 2002, 2020; Landa, 1995);

- Islam in Specific Regions and Towns (Akaev, 2014; Ryazanova, 2019);

- Islamic Economics and Finance (Bekkin, 2020);

- Culture and Education (Buttaeva, 2009; Silantiev, 2005; Pavlova, 2018);

- Unofficial Islam, Radicalism and Extremism (Ignatenko, 2004, 2005; Yakupov, 1971).

In addition, there have been some attempts to introduce a chronological classification of such research. According to R. Agishev (2018), there are several phases in Islamic studies of the Russian Federation.

The first phase lasted from the late 1980s to the mid-1990s. It was characterized by a revival of interest in Islam as a religion but also as a cultural and ideological phenomenon of Russian reality. This period saw formation and development of organizational and management structures of the Muslim community in Russia. The related scientific literature offers remarkable insights into the history of Islam.

The second phase began in the mid-1990s and ended in the late 2000s. Salafist propaganda exacerbated the situation in many regions and radical Islam became the key theme for Islamic studies in the Russian Federation.

The third phase, which started in the second decade of the 21 st century, is characterized by a growing interest in the fundamental principles of Islamic doctrine in Russian regions. The numerous publications written in this period explore how Muslims in different regions preserve their traditions. Scientists emphasize on the specific geographical features of Islam in Russia, using the terms "traditional", "local" or "national" Islam. These expressions bring us to the most discussed concepts concerning the current issues that are related to Islam in Russia. Apart from selecting a general perspective and a topic, research requires understanding the language of scientific description.

In the late 20th century, Islam was "divided" by Russian politicians, academic communities and media. "Traditional", "official", "moderate" or "domestic" Islam was opposed to "untraditional", "unofficial", "radical" or "foreign" Islam.

Even though this classification is largely fictitious, this period was characterized by their confrontation. Russian authorities considered new Islamic branches to be hostile and presented them as ideological foundations of extremism and terrorism. It should be noted that this was primarily a political view on the events in the Muslim regions of the Russian Federation that were taking place during the late 1990s.

After the dissolution of the Soviet Union, these regions were undergoing politicization and radicalization of Islam, or rather the spread of its untraditional interpretations often 


\section{ISLAM AND ITS REFLECTION IN RUSSIAN}

referred to as Wahhabism, Salafism, Fundamentalism and Islamism. However, any generalising attempts face methodological issues, such as those related to the ambiguity of terminology and controversial definitions.

There have been two tendencies since the beginning of the 21 st century: promoting hostile views of radical Islam on one hand and official debates on the development of traditional Islam on the other hand. The roots of "traditional" and "untraditional" Islam as well as the legitimacy of certain deviations from the Islamic doctrine are still the subjects of much debate. According to Akhmetkarimov (2020: 179-202) and also Benussi (2020: 111134), the term "traditional Islam", which started to predominate in the debates on Islam in Russia at the beginning of the new millennium, has several meanings.

Different uses of this expression have both secular and religious connotations. It can be defined as a form of Islam loyalty to state, national ethnic Muslim culture and a folk religion. Traditional Islam appeals to the legacy of long-term relationships between the state and its Muslim citizens, which date back to Catherine the Great and her policy of religious tolerance. Advocates of "traditional" Islam point out its centennial evolution as well as new versions of Muslim rituals.

They realize Islam's enormous potential for adaptation, which enabled development of the harmonic and consistent concept of Russian Islam under specific regional, economic, ethnic and historical conditions. On the other hand, the opponents of "traditional" Islam, who advocate the authority and experience of Muslim leaders in the Persian Gulf region, call for purging Islam in Russia of pagan, Orthodox and other elements and returning to its original foundations.

Despite the wide spectrum of the aforementioned publications, Islam in the Russian Federation is an issue that needs to be further explored owing to several reasons. Firstly, there are different points of view on various aspects of Islam, its followers and opponents. In addition, dynamics of the Islamic factor development in today's Russia constantly bring new circumstances and risks that need to be examined to allow for the development of effective strategies, thus resolving both old and new issues. Lastly, it is necessary to consider contemporary international relations, which add a whole new dimension to the Islamic factor.

\section{Conclusion}

Russia's religious revival currently poses several major challenges, including particularly establishment of religious identity principles, ensuring national values integrity, seeking new logic and philosophy in the national politics and tackling the threats related to religious radicalism.

Following the analysis of the scientific literature on Islamic awakening in the Russian Federation, we can confirm its growing dynamics and thematic diversity. Tackling the Soviet legacy, the revival of new traditions and new challenges of the 21 st century are all very dynamic processes. Debates on these issues are getting more intense due to complicated transformational processes in the Muslim countries as well as socioeconomic and political changes in Russia's Muslim regions, which began after the dissolution of the Soviet Union. These issues remain topical and require further research. 


\section{Acknowledge}

The paper was written as part of the project VEGA 1/0490/19 - The Islamic Factor in the World Economy.

\section{References}

Agishev, R. R. (2018). Studying regional peculiarities of Islam in the Russian Federation in contemporary times. Sovremennyy musul'manskiy mir, 3, 1-10 [in Russian].

Akaev, V. (2014). Religious and Political Elites in Northern Caucasus: Formation, Ideological Contradictions and Practical Opposition. In Religion in Society, Central Asia, and the Caucasus, 15(1), $78-89$.

Akhmetkarimov, B. (2020). Common sense is not so common: Integration and perceptions of 'traditional Islam' in Russia's Volga-Ural region. Contemporary Islam, 14, 179-202.

Anderson, J. (1994). Religion, State and Politics in the Soviet Union and Successor States. Cambridge University Press.

Beissinger, M. R. (2002). Nationalist Mobilization and the Collapse of the Soviet State. CambridgeUniversity Press, Illustrated edition.

Bekkin, R. I. (2010). Islamic economic model and modernity. Moscow: Mardžani [in Russian].

Bekkin, R. I. (2020). The Concept of Traditional Islam in Modern Islamic Discourse in Russia. Sarajevo: Center for Advanced Studies, $87-114$.

Bennigsen, A. (1986). Muslims of the Soviet Empire. A Guide. Indiana University Press.

Bennigsen, A. (2011). The Islamic Threat to the Soviet State. Routledge.

Benussi, M. (2020). "Sovereign" Islam and Tatar "Aqīdah": Normative religious narratives and grassroots criticism amongst Tatarstan's Muslims. Contemporary Islam, 14, 111-134.

Bobrovnikov, V. (2002). Muslims of North Caucasus: traditions, lows and violence. Moscow: Vostochnaia Literatura RAN [in Russian].

Bobrovnikov, V. O. (2007). Sovieticum vs. islamicum: some results and prospects of Islam studies in Russia. Vestnik Evrazii - Acta Eurasica, 3 (37), 8 - 21 [in Russian].

Buttaeva, A. (2009). Islamskoe vozrozhdenie v Rossii / Islamic Revival in Russia. Bulletin of the Dagestan Scientific Center of the Russian Academy of Science, 36 [in Russian].

Corley, F. (1996). Religion in the Soviet Union: An Archival Reader. NYU Press.

Ignatenko, A. A. (2004). Islam and politics. Moscow: Institute of religion and policy.

Ignatenko, A. A. (2005). Inter Terror in Russia. Moscow, Evropa.

Keerana, R. \& Kenny, T. (2010). Socialism Betrayed: Behind the Collapse of the Soviet Union. Publisher iUniverse.

Kudryavtsev, A. A. (2013). Islam in Society and Politics. In Nourzhanov, K. - Christian Bleuer, Ch.: Tajikistan: A Political and Social History. ANU Press.

Landa, R. G. (1995). Islam v istorii Rossii / Islam in the history of Russia. Moscow: Vostochnaya literatura RAN [in Russian].

Malashenko, A. (1994). Islam in Central Asia. Ithaca. 


\section{ISLAM AND ITS REFLECTION IN RUSSIAN}

Malashenko, A. (2007). Russia and Islam. Moscow: Carnegie Moscow Center and ROSSPEN.

Malashenko, A. (2014). Islam in Russia. Russia in Global Affairs, 3.

Mchedlova, M. M. \& Kofanova, E. N. (2020). Russia in Anticipation of Changes: Religious Factor and Socio-political Preferences. RUDN Journal of Political Science, 22 (1), 7-21.

Mirzakhanov, D. G. (2016). Political Islam in contemporary Russia: the historiography of the problem. Izvestiya Saratovskogo Universiteta. Novaya seriya. Sotsiologiya. Politologiya, 16 (4), 466-474 [in Russian].

Pavlova O. S. (2018). The Values and Social Identity of Russian Muslims. In Lebedeva N .Dimitrova, R.-Berry, J. Changing. Values and Identities in the Post-Communist World.Political Science and International Studies. Springer, 99-115.

Prozorov, S. M. (1999). Islam on the territory of former Russia Empire. Entsiklopedicheskii slovar, 2. Moscow: Vostochnaia literature [in Russian].

Prozorov, S. M. (2004). Islam as an ideological system. Vostochnaia Literatura [in Russian].

Ramet, S. P. (2005). Religious Policy in the Soviet Union. Cambridge University Press.

Ryazanova, S. (2019). Migrants and conflicts within the local Ummah of the Perm Krai: A playing card or a social actor? Stanovništvo, 57(1), $97-111$.

Sapronova, M. A., Chechevishnikov, A. L., Yarlykapov, A. A. (2018). Islam and the Muslims of the post-Soviet Russia in the studies of domestic researchers. Bibliographic dictionary. Moscow, MGIMO-Universitet [in Russian].

Sapronova, M.A. -Chechevishnikov, A.L. - Yarlykapov, A. A. (2020). Forming a Scientific Community. A Consolidated Portrait of Researchers of Russian Islam. Polis. Political Studies, 2, pp. 122-136.

Shmelev, A.P., Potapova, Yu. S. (2015). The influence of migration processes on the Muslim community of Russia. Islam v sovremennom mire, 11(2), 145-152 [in Russian].

Silantyev, R. (2005). The recent history of the Russian Islamic community. Moscow: Ichtios [in Russian].

Slatera, W. \& Wilson, A. (2004). The Legacy of the Soviet Union. Palgrave Macmillan.

Web of Science (2021). Results, Analysis. Web of Science Core Collection. Available online at: https://clarivate.com/webofsciencegroup/solutions/web-of-science-core-collection/.

Yakupov, V. (1971). Returning to the true Islam. Kazan.

Yemelianova, G. M. (2002). Russia and Islam: A Historical Survey. Palgrave Macmillan.

Yemelianova, G. M. (2010). Radical Islam in the Former Soviet Union. Routledge.

Yemelianova, G. M. (2019). Muslims of Central Asia: An Introduction. Edinburgh University Press.

Zenkovsky, S. A. (2001). Pan-Turkism \& Islam in Russia. Publisher: Literary Licensing LLC.

Paper submitted

Paper accepted for publishing

Paper published online
14 September 2021

07 November 2021

30 November 2021 